\title{
CHANGE MANAGEMENT IN ISLAM PERSPECTIVE
}

\author{
Hujjatullah Fazlurrahman *)
}

\begin{abstract}
This paper attempts to review the literature on the Islamic values and change management, then presents the importance of its delineated dimensions. Two main theories of Islamic perspective and practices are discussed comprehensively based on the Qur'an verses as the ultimate source in Islamic thinking. The review includes the comparison between certain components' implementations. This reveals that each of dimensions are clearly change management. It suggests that Islamic emphasizes on commercial activities which denied the authors' opinions on its' teaching for not governing the materials aspect or success in change management. The Islamic religion seeks to deliver the goodness to all mankind according to its rules and principles. The integrated system of the Islamic worldview encompasses all aspects of both worldly and hereafterincluding the aspect of change management. Researcher shows that change management in Islam perspective consist of human, development and change.
\end{abstract}

Keywords: Islamic Values, Islamic Practice, Change Management

\section{INTRODUCTION \\ 1.1 Research Background}

Nothing is last forever in the world except for the change itself. This is the analogy of how world is always changing. The theory of change has actually been discovered by Darwin with his evolutionary theory. Darwin's statement is related to the theory of evolution "survival in the fittest", it relates to something that adaptable. Darwin's statements concerning the word's living things that can survive are those who can conform to the state of nature. In other words, Darwin's theory is related to natural selection. This theory can be linked to change management and companies that cannot change with the existing conditions will fall. Companies that can not adjust to the environment will lead to destruction.

We can see some companies that are destroyed because they cannot adjust to market circumstances. Examples of companies that were destroyed because they cannot adjust to the environment among others Nokia, this company once became the king of mobile phone companies in the world. Nokia phones are excellent in the hearts of consumers around the world. But since the existence of smart phones, Nokia did not quickly catch market changes. The second example is Blackberry which once became a pioneer of smart phones, but lost to compete with Samsung and also lost in the market. Samsung used to be scorned by Sony but now Samsung has left Sony so far. Another example recited in Indonesia and still warm in our minds, how Seven Eleven minimarket must close and leave from Indonesia because it cannot compete with other competitors. Examples of those companies that destroyed because of changing can explain that changing is important which also means we are required to adapt to the environment or we will be crushed by the change. This is in line with Darwin's theory of natural selection. After studying the case of company that fall because they cannot adapt with the environment and its relation with Darwin's natural selection theory, the question then why we must change?

\subsection{Research Problem}

Based on the above reasoning, researcher need to investigate how change management concept in Islam perspective. 


\subsection{Research Purpose}

The purpose of this study is to advance the understanding of the change management concept in Islam perspective.

\section{THEORETICAL FRAMEWORK}

\subsection{Theoretical Framework}

\subsubsection{Change Management}

Characteristics of change according to Kasali (2010), first, change are a sign of life. When we were a baby, we really needed the help of others. Then after growing up we begin to reduce dependence on others. So as companies and products that have life cycles like living things that call born, grow, old and die. The life cycle of a product consist of introduction, growth, mature and decline. Many companies entering the introduction phase and directly go to decline phase because they cannot be accepted by the market. The life cycle of products and companies is not much different; it is only different on stages which consist of business (start-up), growth, maturity, and decline. Second, change gives hope. Any change will give hope. We feel there is hope for a better direction in every change of State leaders. But basically, not every change gives convenient hope. If seen from the curve above, a company will grow and then fall down in the phase of maturity. Therefore, they should make changes while they are developing. Examples of company that did not make changes while developing was Nokia, that did not directly respond to the existence of smart phone.

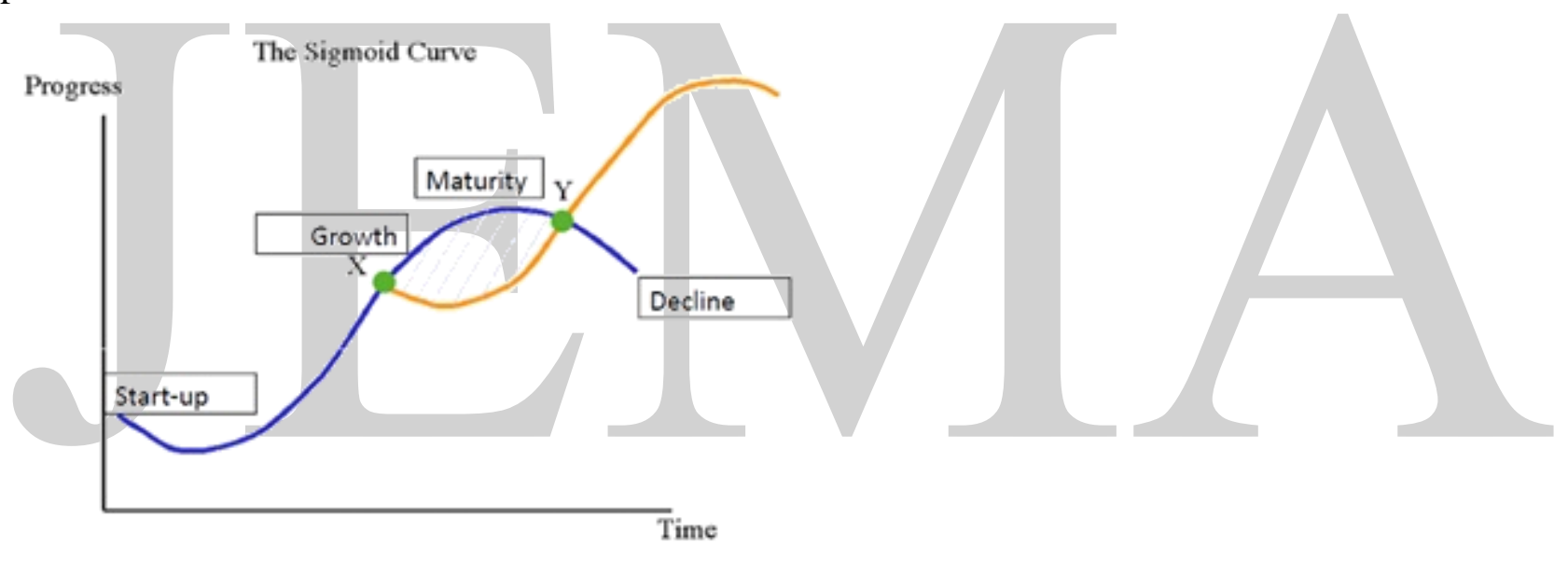

Picture 1 Sigmoid Curve

Every company to pay much by left far behind by competitors. Companies that do not want to make changes feel comfortable with their situation now, this leaving the company stagnant and heading for destruction. Thus, the company must immediately respond to the changing circumstances in order to keep up with the changes. According to Kotter (2002), repulsion to change influence by the company which is first satisfied by the performance of the company. Second, do not want to move or stop in place and protect themselves by do not want to receive input from others. It could be happen because they are panicking and fearful of change. Third, pessimists because fear of change makes many companies do not make changes. Research focuses on qualitative research that includes literature review. Literature review is a book and article from scientific journals that have been identified through the review process repeatedly.

The general objective of organizational change is adjusting to the environment or improvement of organizational performance. Involving organizational changes that change product, technology, administrative and changes in human resources as theory suggests. (Austin \& Claassen, 2008). The main changes are administrative (process) which refers on organizational structure and administrative processes (mainly occur at the level of management) and technical 
(product), changes in the products, services, production or technological processes and work of the organization activities. The concept of metamorphosis and change can be described as below;

\section{Metamorphosis}

Metamorphosis is the change in form or structure, transitional forms. Metamorphosis is the change in form or structure, the tangible changes in the development. Thus the metamorphosis can be interpreted as a real change in organizational and the absolute change of organizationa shape and can not return to previous forms.

\section{Change}

Changes occur because of the emergence of pressures on organizations, individuals, or groups. So, he focused on the statement of "why", which is why can be individuals, groups, or organizational change. From there he had to track down how change can be managed and produce something. Lewin concluded that the pressure forces (driving forces) will be faced with the reluctance (resistances) for change. Changes that might occur by strengthening the "driving forces" it, or weaken "resistances to change".

From there Lewin describes the theory of the change process as a pattern of events that occurred from the beginning of a change until the end. One earliest theory of change process is a model-style field of Lewin that suggested the process of change can be divided into three stages: unfreezing, changing and freezing. Unfreezing is an awareness process for the need or the need for change. Changing is a measures in the form of action, whether strengthening "Driving Forces" and weaken "resistances". While refreezing is an effort to bring back the organization to a new equilibrium (a new dynamic equilibrium). Organizational Change as cited by Irawati A. Kahar states that change is to choose a different action than ever done before. that Differences result a change.

One of fundamental change planning model that proposed by Kurt Lewin (Senior dan Fleming, 2006) with a three step procedure of change. According to Lewin three steps of the procedure are:

a. Searching (Unfreezing) This step usually involves efforts to make lower tensions in an organization to extent that there is at the present time. Unfreezing sometimes achieved by providing information that shows the differences between the desired behavior by members of the organization and the actual behavior that run at the present time.

b. Action (Movement) The second step is to take action that will change the social system of the original behavioral level to a new level of behavior.

c. Freezing (Refreezing) The third step is trying to stabilize the organization at a new equilibrium level. This action is usually achieved through the use of the best mechanism, which encourages organization to new equilibrium. The mechanism that could helps, among others, may be the culture of the organization, organizational norms, policies, and organizational structure.

Table 1. Definiton / Concept of Change management

\begin{tabular}{|l|l|l|}
\hline No & Author & Definiton / Concept of Change management \\
\hline 1. & Kasali (2010) & Sigmoid Curve \\
\hline 2. & Senior \& Fleming (2006) & Unfreezing, move, and refreezing \\
\hline 3. & Tamilarasu (2012) & $\begin{array}{l}\text { is a structured approach to shifting/transitioning } \\
\text { individuals, teams, and organizations from a current state } \\
\text { to a desired future state }\end{array}$ \\
\hline 4. & Kotter (2002) & $\begin{array}{l}\text { Changes in vision, systems, products and culture all have } \\
\text { their roots in behavioral change. }\end{array}$ \\
\hline
\end{tabular}


Table 2 Management Research in Islam Prespective

\begin{tabular}{|l|l|l|}
\hline No & Author & Tittle \\
\hline 1. & Rafiki \& Wahab (2014) & $\begin{array}{l}\text { Islamic Values and Principles in the Organization: A } \\
\text { Review of Literature Asian }\end{array}$ \\
\hline 2. & Branine \& Pollard (2010). & $\begin{array}{l}\text { Human resource management with Islamic management } \\
\text { principles: A dialectic for a reverse diffusion in } \\
\text { management }\end{array}$ \\
\hline 3. & $\begin{array}{l}\text { Zangoueinezhad \& Moshabaki } \\
\text { (2011) }\end{array}$ & $\begin{array}{l}\text { Human resource management based on the index of } \\
\text { Islamic human development }\end{array}$ \\
\hline 4. & Rana \& Malik (2016). & $\begin{array}{l}\text { Human resource management from an Islamic } \\
\text { perspective: a contemporary literature review }\end{array}$ \\
\hline
\end{tabular}

\section{RESEARCH METHOD}

This research can be classified as qualitative research with literature review as the research tools. Qualitative as generated from the broad answers to specific questions in inter- views, or from responses to open-ended questions in a questionnaire, or through observation, or from already available information gathered from various sources (Sekaran, 2003). While literature review in this research obtained from specifically books and book chapters, and the journal papers.

\section{RESEARCH RESULT AND ANALYSIS}

\subsection{Change Management in Islam Perspective}

In assessing change management in Islamic perspective, it starts from human explanation. Humans are the khalifah of the earth, so they are the actor of a change. Then proceed with the development, because humans are creatures that develop from birth to death. Religion doctrine also explains that we must become a better human being. The last stage is change, if we do not change, then we will be crushed by the change itself.

\subsection{Human}

The Islamic context in this change management begins with the creation of man. Man was created by Allah SWT as a perfect being. This is also evidenced by the theory that was discovered by Darwin about natural selection. Man is a creature created by Allah SWT who has the most adaptive of change. Man can survive until now because adaptive to environment. Different from the great and powerful dinosaurs, they cannot survive until today.

Development is all encompassing, beginning from the moral and spiritual development of man and manifested eventually into physical development. According to the Qur'an, man's basic qualification for being the representative of Allah on earth is possession of knowledge. Allah said (2:30-33) that And (mention, O Muhammad), when your Lord said to the angels, "Indeed, I will make upon the earth a successive authority." They said, "Will You place upon it one who causes corruption therein and sheds blood, while we declare Your praise and sanctify You?" Allah said, "Indeed, I know that which you don't know." And He taught Adaam the name -all of them. Then He showed them to the angels and said, "Inform Me of the names of these, if you are truthful." They said, "Exalted are You, we have no knowledge except what You have taught us. Indeed, its You who is the Knowing, the Wise." He said, "O Adam, inform them of their names." And when he had informed them of their names, He said, "Did I not tell you that I know the unseen (aspects) of the heavens and the earth? And I know what you reveal and what you have concealed". Allah also said (39:9) that ".....Are those who know equal to those who do not know? Only they will remember (who are) people of understanding."

According to Majid (2004), Basic natural law of all is "change and development", because all of these things are Allah's creation and developed by Him in an incessant process. This statement explains that humans are created to keep develop and change. Both of these things have become 
human nature created by Allah SWT. Besides, humans are created to always grow and grow in a better direction.

\subsection{Development}

Al-Mujadila 58:11 "O you who believed, when you are told, "Space yourselves" in assemblies then make space, Allah will make space for you. And when you are told, "Arise" then arise, Allah will raise those who have believed among you and those who were given knowledge, by degrees. And Allah is Acquinted with what you do." The verse has given doctrine about capacity building. We are encouraged to increase the scientific and skill capacity that we have wherever we are. This is in accordance with the opinion of Rafiki \& Wahab (2014) about the concept of self-development in the Qur'an. Rasulullah SAW said: "Demanding knowledge is an obligation for every Muslim man and woman". Allah gives the virtue and glory to those who are knowledgeable. Hadith and verse of Qur'an above shows that we are required to study science or in other words increase our knowledge capacity in order to develop to be better. "But those who believed and did righteous deeds- We charge no soul except within its capacity. Those are the companions of paradise, they will abide therein eternally" (al-A'raf: 42). In this verse we are asked to run the worship that is no longer a liability or burden but willingness or a need. This is also in line with what Rafiki \& Wahab (2014) statement about the continuous improvement in the concept of Qur'an.

Ali (2005) explained that performance appraisal in Islam is based on normative instructions and the practice of the Prophet Muhammad as well as of his immediate following four Caliphs. The normative realm is revealed in Qur'anic instructions. According to Ali (2005), the Qur'an clarifies what one does is solely his or her responsibility and no one should be held responsible for the mistakes of others. Employees are expected to have a moral duty to monitor their performance.

\subsection{Changes}

Humanity and development are two very relevant things. In line with the characteristics of change, according to kasali (2010) that the nature of change is due to the omens life. Therefore, after we discuss about development then we will discuss the nature of change in the Qur'an and hadith. The first verse, QS Al-Anfal [8]: verse 53 said "That is because Allah would not change a favor He had bestowed upon a people, until they change what is within themselves. And indeed Allah is Hearing and Knowing." This verse explains blessing given by Allah SWT. If we do not change that blessing then Allah will not change that blessing too. This corresponds to a sigmoid curve that explains if we do not change while the company developing, then we will reach the level of maturity. Hence, the sigmoid curve suggests making changes while we develop. The problem of the above changes in accordance to the Qur'an Surah Ar-rad verse 11, Allah Almighty says Allah does not change the condition of a people until they change what is within themselves. And if Allah wills hardship for a people there is no turning it back; and there is no protector for them but Allah". This verse explains that if we change, we will be crushed by the change. In accordance with the sigmoid curve explaining that after the company develops then the next level is maturity. At this level, company must make changes (or jump to the second curve) otherwise it will lead to the gate of destruction. Corresponding with the doctrine above that Allah will not change people if they do not change themselves. Just as the company, if the company does not want to change it will lead to the gate of destruction. "Whoever has day (today) better than yesterday, than she/he has been lucky, whoever has day as same as yesterday, then she/he has suffer lost, and whoever has day worse than yesterday, then she/he belongs to the cursed". Whoever has the same two days (today and yesterday) are equal then she/he has suffer lost, anyone whoever has day worse than yesterday then she/he classified as cursed." The origin of this hadith is unknown except in the dream of 'Abd' aziz Bin Abi rawaad, he says "The Prophet had will to me in a dream, with the added word at the end" (HR al-baihaqy), the possible additional content is "Whoever has no additional in her/his day then he/she is in deprivation". In the above hadith explained that Rasulullah SAW asked us to be better every day from time to time. It aims to improve our ability and capacity in life. In addition, to face a 
changing world, we are required to improve ourselves every day. Nothing lasts forever except the change its self, therefore we must improve ourselves every day, month and years so as not to be crushed by the change.

Table 1 Change Management in Al Qur'an

\begin{tabular}{|l|l|l|}
\hline No & Subject & Al-Qur'an Verses \\
\hline 1 & Humanism & Al Qashash: 20, an-nas, \\
\hline 2. & Development & Al-Mujadila 58:11, hadits \\
\hline 3. & Changes & Ar-rad ayat 11, Al-Anfal [8]: ayat 53 \\
\hline
\end{tabular}

\section{RESEARCH CONCLUSION AND LIMITATION}

\subsection{Conclusion}

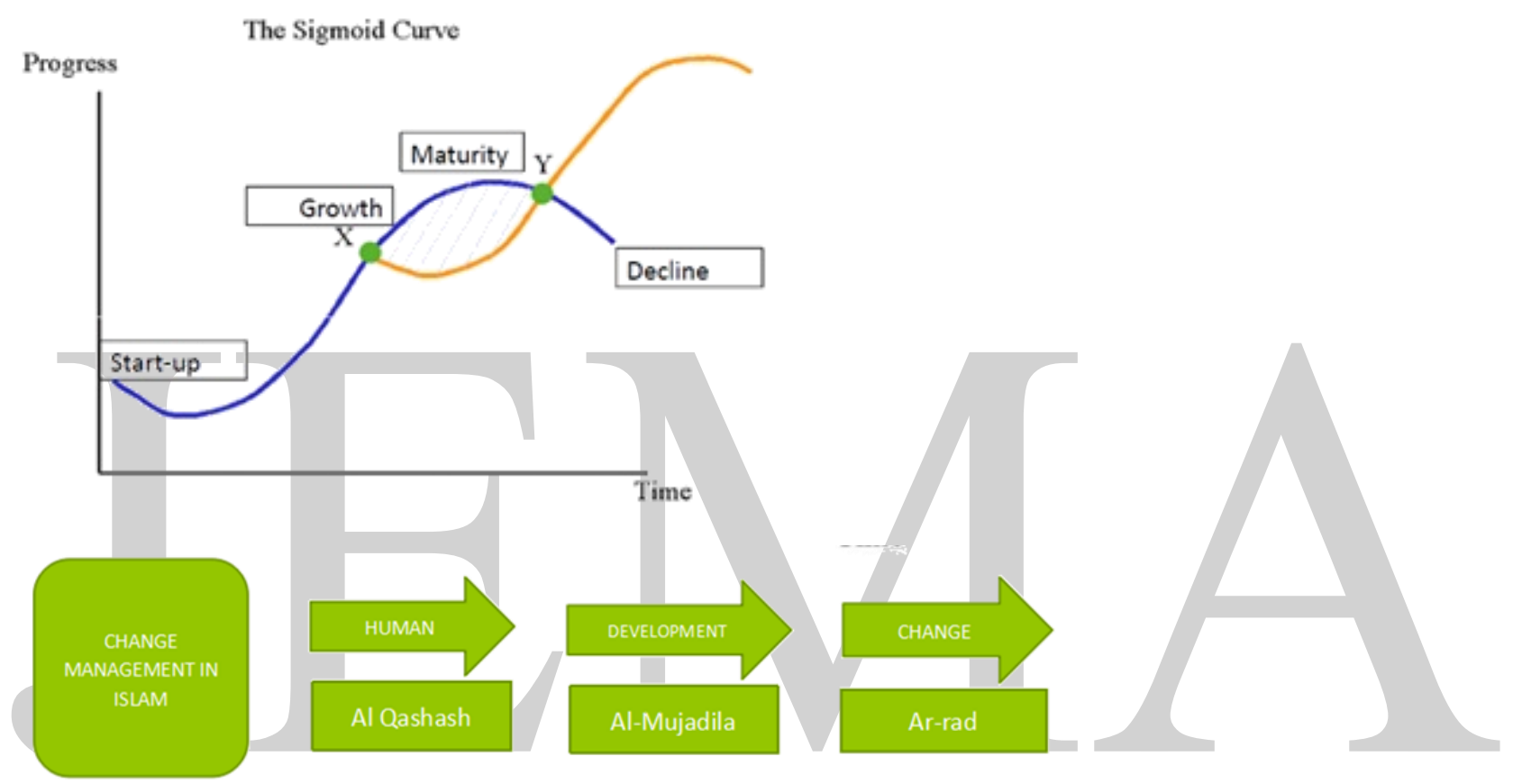

Picture 2 Change Management in Islam Prespective

Change Management in Islam perspective consists of three phases which are human, development, and changes. This is in accordance with the existing sigmoid curve above. Companies are required to make changes as the company develops. It corresponds to the Qur'an and hadith. Therefore, the change management conceptual is in accordance with the way of Islam (Islam perspective).

\subsection{Limitation}

This research is limited to contextual understanding of change management by integrating and intrepretating the change management theory with Qur'an and hadith.

\section{REFERENCES}

Zangoueinezhad, A., \& Moshabaki, A. (2011). Human Resource Management Based On The Index of Islamic Human Development. International Journal of Social Economics, 38(12), 962-972.

Ali, A. (2005). Islamic Perspectives on Management and Organization. Cheltenham and Northampton, MA : Edward Elgar.

Al-Qur'an. 
Austin, M., \& Claassen, J. (2008). Impact Of Organizational Change On Organizational Culture: Implications For Introducing Evidence-Based Practice, Journal of Evidence-Based Social Work, 5(1/2), 321-359.

Branine, M., Pollard, D. (2010). Human Resource Management with Islamic Management Principles: A Dialectic for a Reverse Diffusion in Management Personel Review. Farnborough 39(6), 712-727.

Kasali, R. (2010). Change!: Manajemen Perubahan dan Manajemen Harapan. Jakarta: Gramedia Pustaka Utama.

Kotter, J. P \& Cohen, D. S. (2002). The Heart of Change : Real-Life Stories of How People Change Their Organizations. Boston: Harvard Business Press.

Majid, N. (2003). Islam Doktrin Dan Peradaban: Sebuah Telaah Kritis Terhadap Masalah Keimanan, Kemanusiaan Dan Kemodernan. Jakarta: Paramadina Press.

Rafiki, \& Wahab. (2014). Islamic Values and Principles in the Organization: A Review of Literature Asian, 10(9).

Rana, M. H., Malik, M. S. (2016). Human Resource Management From An Islamic Perspective: A Contemporary Literature Review. International Journal of Islamic and Middle Eastern Finance and Management, 9(1), 109-124.

Sekaran, U. (2003). Research Method for Business: A Skill Building Approach, 4th Edition, John Wiley \& Sons Agarwal, A., Garg, S., \& Pareek, U. 2011. Strengthening Human Resource Practices in Healthcare in India: The Road Ahead. Journal Indian Academy of Clinical Medicine, 12(1), 39.

Senior, B., \& Fleming, J. (2006). Organizational Change, (3rd ed). New Jersey: Prentice Hall.

Tamilarasu, V. (2012). Change Management, International Journal of Management Prudence, 4(2), 26-31.

*) Hujjatullah Fazlurrahman, State University of Surabaya, Surabaya, Indonesia (E-Mail: hujjatulahfazlurrahman@unesa.ac.id) 